Participative Journal: Jurnal Pengabdian Pada Masyarakat

Vol. 01, No. 02, September 2021 | Page 82-92

E-ISSN 2776-2971, P-ISSN 2776-5954

Journal homepage: https://jurnal.jurmat.com/index.php/pj/index

\title{
Dampak kebijakan pengalihan dana Desa terhadap perekonomian masyarakat Desa Malaka Kabupaten Lombok Utara akibat Covid-19
}

Fatia Rahmanita ${ }^{1 *}$, Wirawan Jamhuri2 ${ }^{2}$

* Affiliasi: Fakultas Tarbiyah dan Keguruan, Universitas Islam Negeri Mataram

Keywords:

Covid-19

Diversion of funds

Community's

economy

\begin{abstract}
A b s t $\mathbf{r}$ a c t: Covid-19 is a disease caused by the Corona virus that emerged at the end of 2019 in Wuhan, China and has spread so rapidly almost troughout the world that is status was declared as Pandemic Covid-19 by the world health agency (WHO) on March 11, 2020. This virus is not only infecting health but also causes various crises in various sectors of community life, especially in the economic field. Therefore, Malaka Village, Pemenang Subdistrict, Nort Lombok Regency, which incidentally is a tourism area visited by many foreign tourist, experienced a drastic decline in the economy caused by the Covid-19 virus. Various efforts were made by the Village Government to cope with the impact of Covid-19, one of them was by diverting village funds. Initially to be allocated for the construction of infrastructure damage by the 2018 earthquake as an aid funds to support the local community's economy.
\end{abstract}

A b s t r a k: Covid 19 merupakan penyakit akibat virus Corona yang muncul pada akhir 2019 di Wuhan, China dan telah merebak begitu pesat hampir di seluruh dunia sehingga statusnya diberlakukan sebagai Pandemi Covid 19 oleh badan kesehatan dunia (WHO) pada tanggal 11 Maret 2020. Virus ini bukan hanya menjangkiti kesehatan akan tetapi juga menyebabkan berbagai krisis di berbagai sektor kehidupan masyarakat khususnya pada bidang perekonomian. Oleh karena itu Desa Malaka, Kec. Pemenang, Kab. Lombok Utara, yang notabenenya merupakan daerah pariwisata yang banyak didatangi oleh wisatawan asing, mengalami penurunan drastis pada bidang perekonomian yang disebabkan oleh virus Covid 19 ini. Berbagai upaya dilakukan oleh Pemerintah Desa untuk menanggulangi dampak Covid 19, salah satu diantaranya dengan melakukan pengalihan dana desa yang awalnya hendak dialokasikan untuk pembangunan infrastruktur yang rusak

\footnotetext{
${ }^{1}$ Corresponding author: Program Studi Pendidikan Bahasa Arab, UIN Mataram, Jl. Gajah Mada Jempong, Indonesia (83116), E-mail addresses: 180102027.mhs@,uinmataram.ac.id

2 Prodi Pendidikan Bahasa Arab, Universitas Islam Negeri Mataram, E-mail Addresses: wirawanjamhuri@uinmataram.ac.id
} 
akibat gempa tahun 2018 silam menjadi dana bantuan untuk menunjang perekonomian masyarakat setempat.

\section{Pendahuluan}

Pada akhir tahun 2019 Indonesia dan Dunia dihebohkan dengan adanya virus baru yang dinamakan dengan virus Corona. Virus ini menyerang alat pernapasan manusia yang berupa cairan yang pekat pada paru-paru yang berperan sebagai tempat pertukaran gas O2 dan CO2 sehingga menyebabkan seseorang kesulitan bernafas, bahkan apabila tak teratasi dapat menyebabkan kematian dalam waktu yang singkat. Hal ini yang menjadikan masyarakat menjadi sangat takut dengan virus ini. Didukung dengan berita yang beredar dari media televisi dan juga internet memberitakan virus ini begitu tragis apabila telah menjangkiti tubuh seseorang dan dapat menular dengan sangat cepat dari tubuh satu ke tubuh lainnya, hanya dengan melalui perantara sentuhan kulit, pakaian, uang, atau benda apapun yang disentuh oleh penderita. Oleh karena itu, semenjak kemunculannya masyarakat dihimbau untuk selalu mengenakan masker, tidak bersentuhan tangan, serta menghindari kerumunan. Pemberitaan mengenai data masyarakat yang terjangkit virus Covid-19 sekian hari semakin meningkat. Dan hal ini sangat meresahkan masyarakat di seluruh dunia.

KKP-DR (Kuliah Kerja Partisipatif-Dari Rumah) merupakan salah satu bentuk kegiatan pengabdian kepada masyarakat yang dilakukan oleh mahasiswa dan mahasiswi di Perguruan Tinggi, guna mempraktikkan ilmu yang telah didapat selama proses perkuliahan. KKP-DR yang awal mulanya dikenal dengan istilah KKN (Kuliah Kerja Nyata) telah mengalami pergeseran kata dari "Nyata" menjadi "Partisipatif-Dari Rumah" ini dilatar belakangi karena virus Covid-19 yang menyita hampir seluruh kegiatan masyarakat yg menimbulkan suatu perkumpulan. Oleh karena itu, pihak P2M LPM UIN Mataram menggunakan istilah KKP-DR agar lebih tepat pada saat wabah Corona ini. KKP-DR juga tidak hanya menyiratkan istilah yang berbeda, namun maknanya berbeda dari KKN. Apabila KKN, mahasiswa dituntut untuk aktif mengadakan suatu program di Desa. Dan hal tersebut dirasa memberatkan mahasiswa pada masa pandemi yang serba minim ini. Sedangkan KKP-DR memiliki makna bahwa mahasiswa berpartisipasi dalam program-program yang dilaksanakan oleh Desa daerah tempat tinggalnya, dan beberapa kegiatan lain yang telah ditetapkan oleh pihak P2M LPM UIN Mataram.

Dana desa adalah dana yang bersumber dari Anggaran Pendapatan dan Belanja Negara yang diperuntukkan untuk menciptakan kemandirian desa dengan melakukan pembangunan, pembinaan, dan pemberdayaan masyarakat. Tujuan diberikannya dana desa adalah untuk mewujudkan desa mandiri dengan cara melaksanakan pembangunan dan memberdayakan masyarakat dengan memanfaatkan potensi yang ada pada desa yang bersangkutan. Prioritas dari

Rahmanita \& Jamhuri (2021), Dampak kebijakan pengalihan.........

| Vol. 01, No.02, 2021 | h. 83 
dana desa tersebut adalah pengembangan produk unggulan kawasan perdesaan, pembagunan Badan Usaha Milik Desa (BUMDes), dan sebagainya. ${ }^{3}$

Fenomena bencana dunia yang terjadi saat ini telah memberikan dampak bagi negara Indonesia. Hal ini dapat dilihat dari lumpuhnya perekonomian masyarakat baik dibidang pemerintahan maupun swasta. Adanya virus Covid-19 ini mengharuskan pemerintah untuk menggeserkan alokasi dana yang ada baik di pusat maupun daerah ${ }^{4}$.

Menurut BPKB (Badan Pengawasan Keuangan dan Pembangunan) Perubahan APB Desa yang telah ditetapkan dalam peraturan desa dimungkinkan untuk dilakukan perubahan apabila terjadi: ${ }^{5}$

1. Keadaan yang menyebabkan harus dilakukan pergeseran antar jenis belanja;

2. Keadaan yang menyebabkan sisa lebih perhitungan anggaran (SLPA) tahun sebelumnya harus digunakan dalam tahun berjalan;

3. Terjadi penambahan atau pengurangan dalam pendapatan pada tahun berjalan; atau

4. Terjadi peristiwa khusus, seperti bencana alam, krisis politik, krisis ekonomi, atau kerusuhan sosial yang berkepanjangan;

5. Perubahan mendasar atas kebijakan pemerintah pusat dan pemerintah daerah.

Berdasarkan latar belakang tersebut, pengabdi mengambil penelitian yang berjudul dampak pengalihan dana desa terhadap perekonomian masyarakat desa Malaka, Kec. Pemenang, Kab. Lombok Utara akibat Covid-19.

\section{Metode}

Metode yang digunakan untuk mencapai tujuan yang direncanakan dalam kegiatan pengabdian ini adalah metode: 1) Penelitian Kualitatif, yaitu penggambaran mengenai proses kegiatan pengabdian di masyarakat, dan penjabaran mengenai data APBDes, 2) Partisipatif action, yaitu kegiatan yang dilakukan dalam bentuk aksi nyata dimana secara langsung peneliti membantu mensukseskan program yang ada di Desa; 3) Wawancara, untuk mendapatkan sumber data primer berupa respon dari warga masyarakat mengenai dampak kebijakan pengalihan dana desa. Sedangkan sumber data sekunder adalah data yang diperoleh resmi dan berbagai literatur yang relevan dengan pembahasan penelitian ini. Sehingga peneliti dapat memecahkan atau menyelesaikan penelitian dengan baik.

\section{Hasil dan Pembahasan}

Desa Malaka, Kec. Pemenang, Kab. Lombok Utara merupakan salah satu desa yang ada di Provinsi Nusa Tenggara Barat, dan terkenal dengan sektor pariwisatanya. Hal ini terlihat dari keindahan panorama pantai yang ada di desa tersebut. Contohnya seperti pantai Klui, Setangi

\footnotetext{
${ }^{3}$ Fadli Faturrahman, M. Saleh, Mega Trishuta Pathiassana, Eka Haryanti. Perubaban Alokasi Anggaran Dana Desa Terbadap Pencegahan Covid-19 Di Kecamatan Moyo bulu. Jurnal Tambora Vol. 4 No. 2A Juli 2020

${ }^{4}$ Ibid

${ }^{5} \mathrm{Ibid}$
}

Rahmanita \& Jamhuri (2021), Dampak kebijakan pengaliban..........

| Vol. 01, No.02, 2021 | h. 84 
yang disana biasanya digunakan sebagai tempat untuk mengadakan camp karna merupakan spot yang indah untuk melihat matahari terbenam. Dan pantai lainnya seperti, pantai Nipah, pantai Pandanan, Pantai Kecinan, dan Pantai Teluknara. Oleh karena potensi pariwisata yang begitu baik di desa Malaka tersebut Pemerintah Desa Malaka berusaha membangun Homestay yang terletak di Pantai Kecinan sebagai Badan Usaha Milik Desa (BUMDes) pada tahun 2021 ini, yang disahkan oleh Bupati Lombok Utara pada tanggal 22 Juli 2021.

Kondisi masyarakat yang ada di Desa Malaka sebagian besar menggantungkan perekonomiannya pada pariwisata yang ada. Sebagian mereka ada yang berprofesi sebagai guide yang siap untuk menemani para wisatawan asing. Sebagian besar juga banyak yang bekerja di hotel-hotel yang terdapat pesisir pantai, dan sebagian besar juga mereka membuka lapak yang menjual ikan bakar di pinggiran pantai.

Namun dengan adanya virus Covid-19, banyak menyebabkan krisis. Dan krisis yang paling dirasakan adalah krisis ekonomi. Karena adanya PSBB dan PPKM yang menyebabkan sektor pariwisata semakin sepi oleh pengunjung. Hal itu menyulitkan perekonomian masyarakat menengah kebawah, karena PSBB dan PPKM ini membatasi seluruh aktivitas masyarakat hingga jam 8 malam saja. Oleh karena dampak dari pandemi Covid-19 terhadap Indonesia, membuat pemerintah pusat mendorong penggunaaan dana desa untuk menanggulangi Covid-19.

Pemerintah pusat membuat payung hukum berupa Peraturan Pemerintah Pengganti Undang-Undang (Perppu) Nomor 1 Tahun 2020 tentang Kebijakan Keuangan Negara dan Stabilitas Sistem keuangan untuk Penanganan Pandemi Covid-196, Perpres No. 54 Tahun 2020 tentang Perubahan Postur dan Rincian Belanja Anggaran pendapapatan dan Belanja Negara TA 2020, di Pasal 2 Ayat 2 yang berbunyi: Anggaran Dana Desa sebagaimana di maksud dalam pasal 1 ayat 4 huruf $b$ dapat digunakan antara lain untuk jaring pengaman sosial di desa berupa bantuan langsung tunai kepada penduduk miskin di desa dan kegiatan penanganan wabah Covid-19, PMK No. 40/PMK.07/2020 tentang Perubahan atas PMK No 205/PMK.07/2019 tentang Perubahan Dana Desa ${ }^{8}$, Peraturan Menteri Desa Nomor 6 Tahun 2020 tentang Perubahan atas Permendesa PDTT Nomor 11 Tahun 2019 tentang Prioritas Penggunaan Dana Desa ${ }^{9}$, Intruksi Menteri Dalam Negeri Nomor 3 Tahun 2020.

Atas landasan peraturan tersebut, Pemerintah Desa Malaka Kec. Pemenang, Kab. Lombok Utara khususnya mengalokasikan dana desa yang awalnya digunakan untuk perbaikan berbagai infrastruktur yang rusak akibat gempa tahun 2018 silam, dialihkan menjadi dana bantuan perekonomian bagi masyarakat setempat. Contohnya seperti, bantuan langsung tunai (BLT) yang berupa uang tunai, BST (Bantuan Sosial Tunai), PKH (Program Keluarga Harapan) yang berupa

\footnotetext{
${ }^{6}$ Perppu. 2020. Tentang Kebijakan keuangan Negara dan stabilitas Sistem Keuangan untuk Penanganan Pandemi Corona Virus Disease 2019 (Covid-19). (Online), (https://kemenkeu.go.id), diakses 3 Agustus 2021.

7 Perpres. 2020. Perubahan Postur dan Rincian Anggaran Pendapatan dan Belanja Negara Tahun Anggaran 2020. (Online), (https://kemenkeu.go.id), diakses 3 Agustus 2021.

${ }_{8}$ PMK, 2020. Pengelolaan Transfer ke Daerah dan dana Desa Tahun Anggaran 2020. (Online), (www.djpk.kemenkeu.go.id), diakses 3 Agustus 2021.

${ }^{9}$ Permendes PDTT, 2020. Prioritas Penggunaan dana Desa Tahun 2020. Online), (https://kemenkeu.go.id), diakses 3 Agustus 2021.
}

Rahmanita \& Jamhuri (2021), Dampak kebijakan pengalihan.........

| Vol. 01, No.02, 2021 | h. 85 
beras sembako, dan pembangunan homestay di Pantai Kecinan sebagai Badan Usaha Milik Desa (BUMDes) yang pekerjanya dikhususkan untuk warga Desa Malaka yang tidak memiliki pekerjaan. Beberapa hal ini dilakukan pemerintah desa setempat untuk meringankan warga masyarakat yang kehilangan pekerjaannya akibat virus Covid-19.

Berikut adalah data mengenai alokasi dana desa tahun $2020^{10}$

\begin{tabular}{lc}
\hline Pendapatan & \\
\hline PADES & $36,000,000$ \\
Hasil usaha & $36,000,000$ \\
Bagi Hasil BUM Desa & $36,000,000$ \\
Sub Bidang Pariwisata & $25,061,000$ \\
Pengembangan Pariwisata Tingkat Desa & $25,061,000$ \\
Belanja Modal ADD $\quad 25,061,000$ \\
Bantuan Sarana dan Prasarana Kelompok Sadar Wisata & $25,061,000$ \\
02 ADD & $25,444,039$ \\
Sub Bidang Penanggulangan Bencana & \\
Penanggulangan Bencana & $50,000,000$ \\
\hline
\end{tabular}

Sedangkan data alokasi dana pada tahun 2021 adalah $^{11}$ :

\begin{tabular}{|c|c|}
\hline Hasil usaha & \\
\hline Bagi hasil BUM Desa & $14,000,000$ \\
\hline Alokasi Dana Desa (ADD) & $1,057,983,000$ \\
\hline $\begin{array}{l}\text { BIDANG PENANGGULANGAN BENCANA, } \\
\text { KEADAAN DARURAT DAN MENDESAK DESA }\end{array}$ & $1,101,600,000$ \\
\hline Sub Bidang Penanggulangan Bencana & - \\
\hline Penanggulangan Bencana & - \\
\hline Sub Bidang Keadaan Darurat & - \\
\hline Keadaan Darurat & - \\
\hline Sub Bidang Keadaan Mendesak. & $1,101,600,000$ \\
\hline Belanja Tak Terduga & $1,101,600,000$ \\
\hline JUMLAH BELANJA & $3,100,054,000$ \\
\hline \multicolumn{2}{|l|}{ 10 Lampiran APBDes Desa Malaka Tahun 2020} \\
\hline manita \& Jamhuri (2021), Dampak kebija & | Vol. 01, No.02, 202 \\
\hline
\end{tabular}


Dari gambaran data mengenai pengalokasian dana desa yang terhitung sejak tahun 20202021 terdapat perbedaan yang sangat jelas, dimulai dari Pendapatan BUMDesa yang sangat berkurang, akibat Covid 19 yang semakin menurunkan pendapatan dari Badan Usaha Milik Desa. Sebaliknya pada bidang penanggulangan bencana terjadi peningkatan kebutuhan dana dari tahun 2020 menuju 2021, ditambah lagi dengan adanya sub bidang keadaan mendesak dan belanja tak terduga yang didalamnya meliputi beberapa bantuan untuk meringankan perekonomian masyarakat desa akibat Covid-19.

\section{Partisipatif Action}

Pengabdi ikut terjun langsung ke lapangan untuk membantu mensukseskan kegiatan pembagian bantuan bagi masyarakat yang ekonominya menengah ke bawah. Seperti bantuan BLT (Bantuan Langsung Tunai) yang berupa uang sebanyak 300.000/bulan, kemudian bantuan PKH (Program Keluarga Harapan) yang berupa beras sembako, kemudian pembangunan Homestay di Dusun Kecinan sebagai BUMDes (Badan Usaha Milik Desa) yang para pekerjanya adalah masyarakat desa setempat yang tidak memiliki pekerjaan.

Berikut dokumentasi kegiatan-kegiatan yang dilakukan oleh Pemerintah Desa untuk membantu perekonomian masyarakat Desa Malaka, Kec. Pemenang, Kab. Lombok Utara

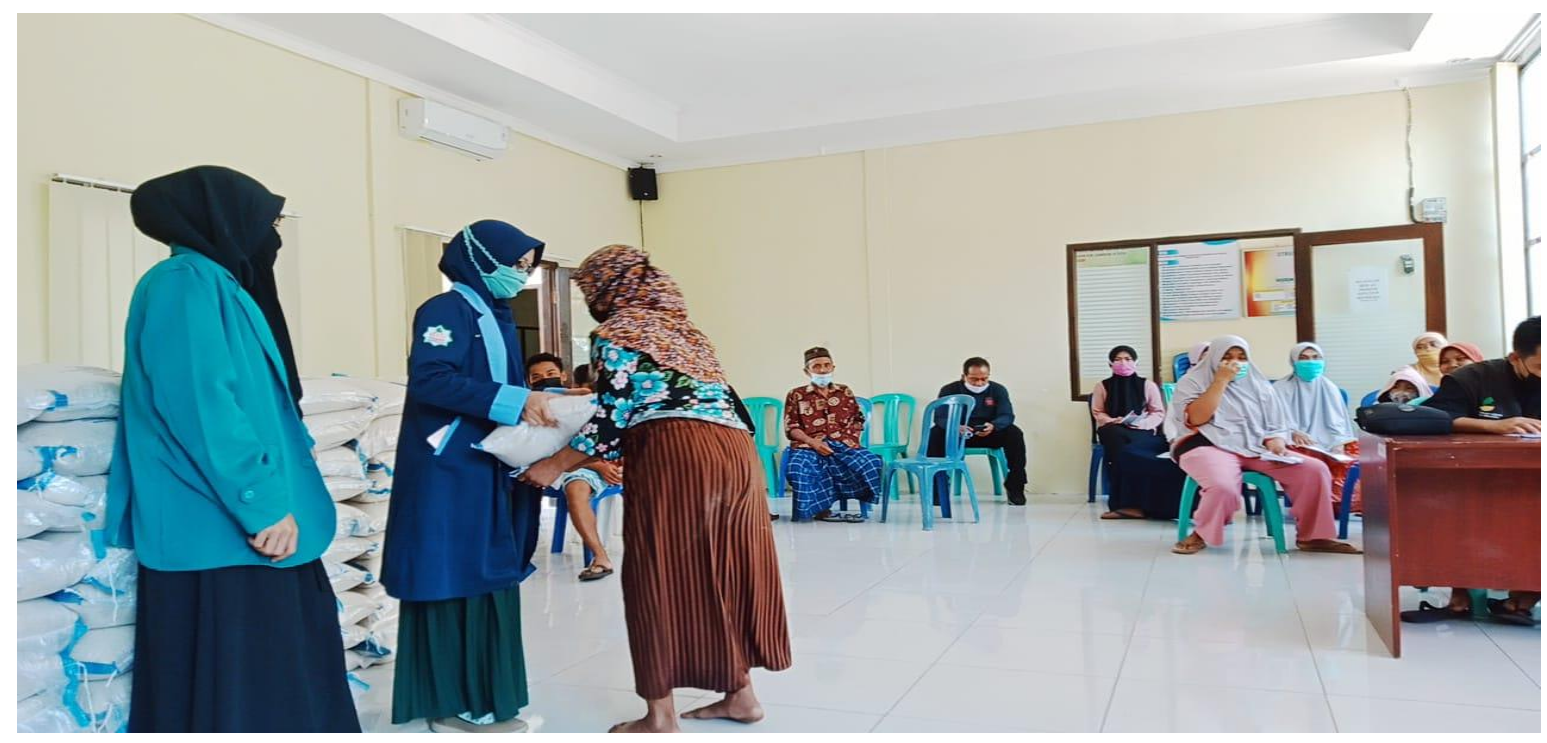

Gambar 1. Foto diatas merupakan kegiatan pembagian bantuan PKH atau Program Kerja Harapan. ${ }^{12}$

${ }^{12}$ Foto diatas merupakan kegiatan pembagian bantuan PKH atau Program Kerja Harapan berupa beras sembako untuk masyarakat ekonomi menengah kebawah di desa Malaka pada hari kamis tanggal 29 Juli 2021 


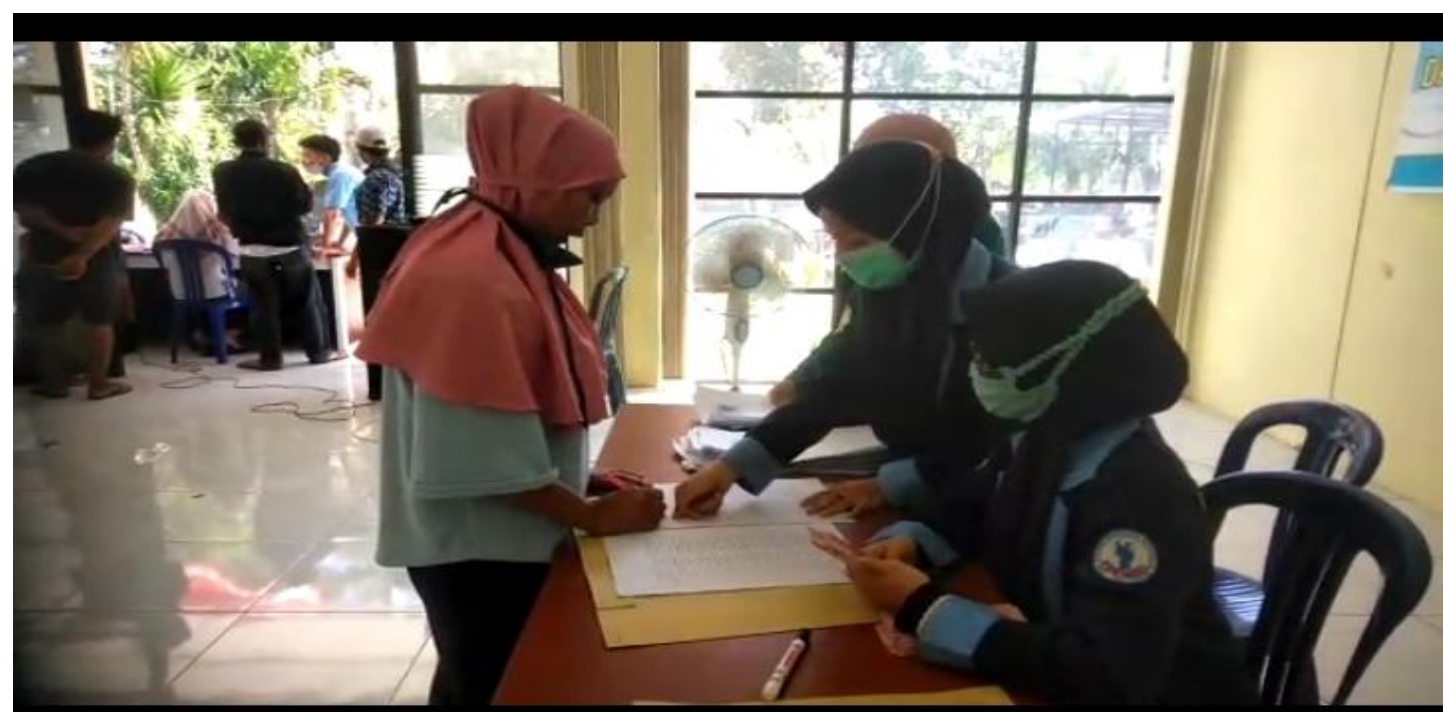

Gambar 2. Foto diatas merupakan kegiatan pembagian Bantuan Langsung Tunai (BLT) tahap kelima $^{13}$

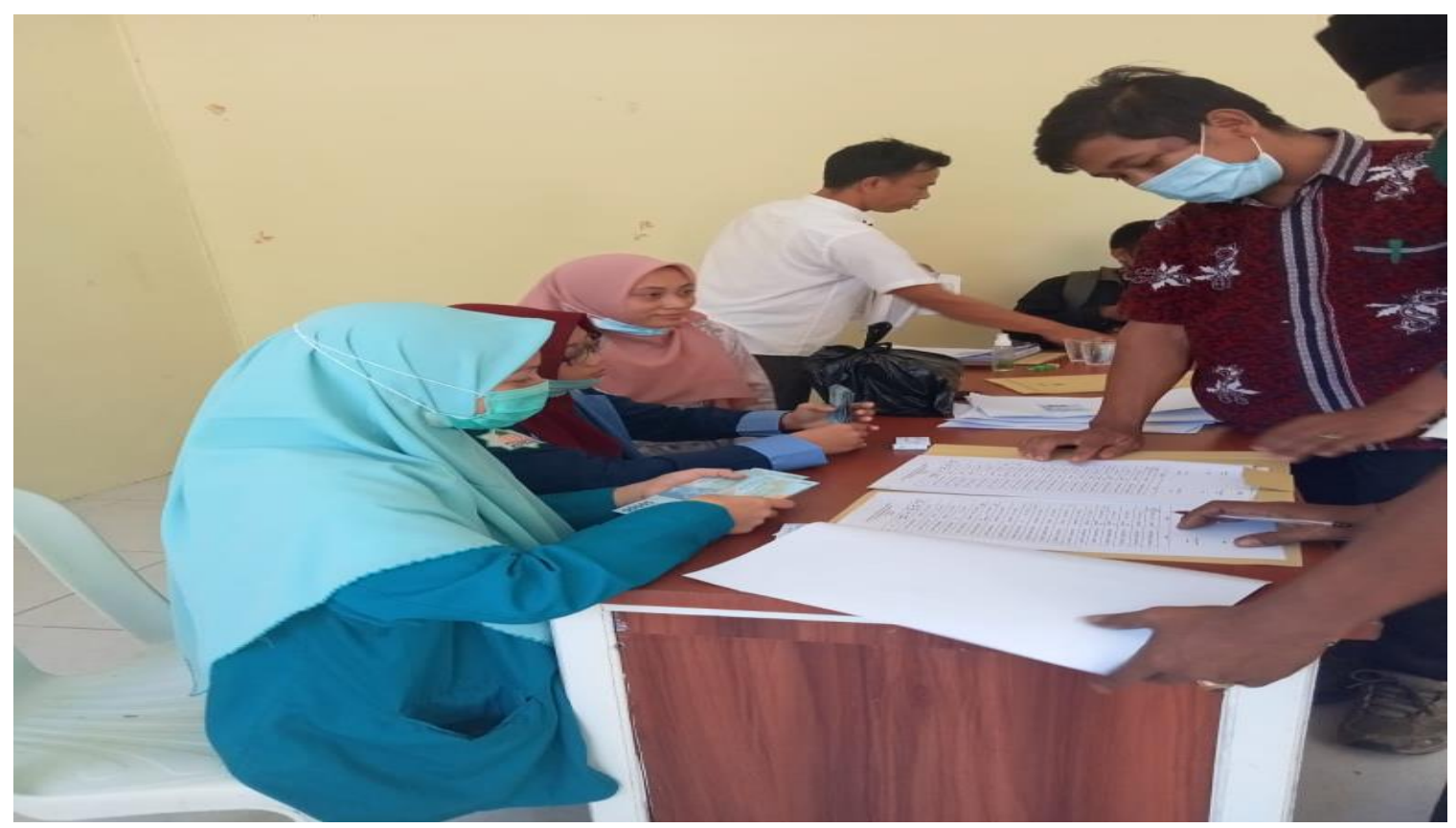

Gambar 3. merupakan pembagian BLT tahap ke VI dan VII untuk 2 bulan. ${ }^{14}$

${ }^{13}$ Foto diatas merupakan kegiatan pembagian Bantuan Langsung Tunai (BLT) tahap kelima sebesar 300.000 perorang di Kantor Desa Malaka, Kec. Pemenang, Kab. Lombok Utara pada hari Rabu tanggal 14 Juli 2021

${ }^{14}$ Foto tersebut merupakan kegiatan pembagian BLT tahap ke VI dan VII untuk 2 bulan sebesar 600.000 per individu pada hari Rabu tanggal 04 Agustus 2021 


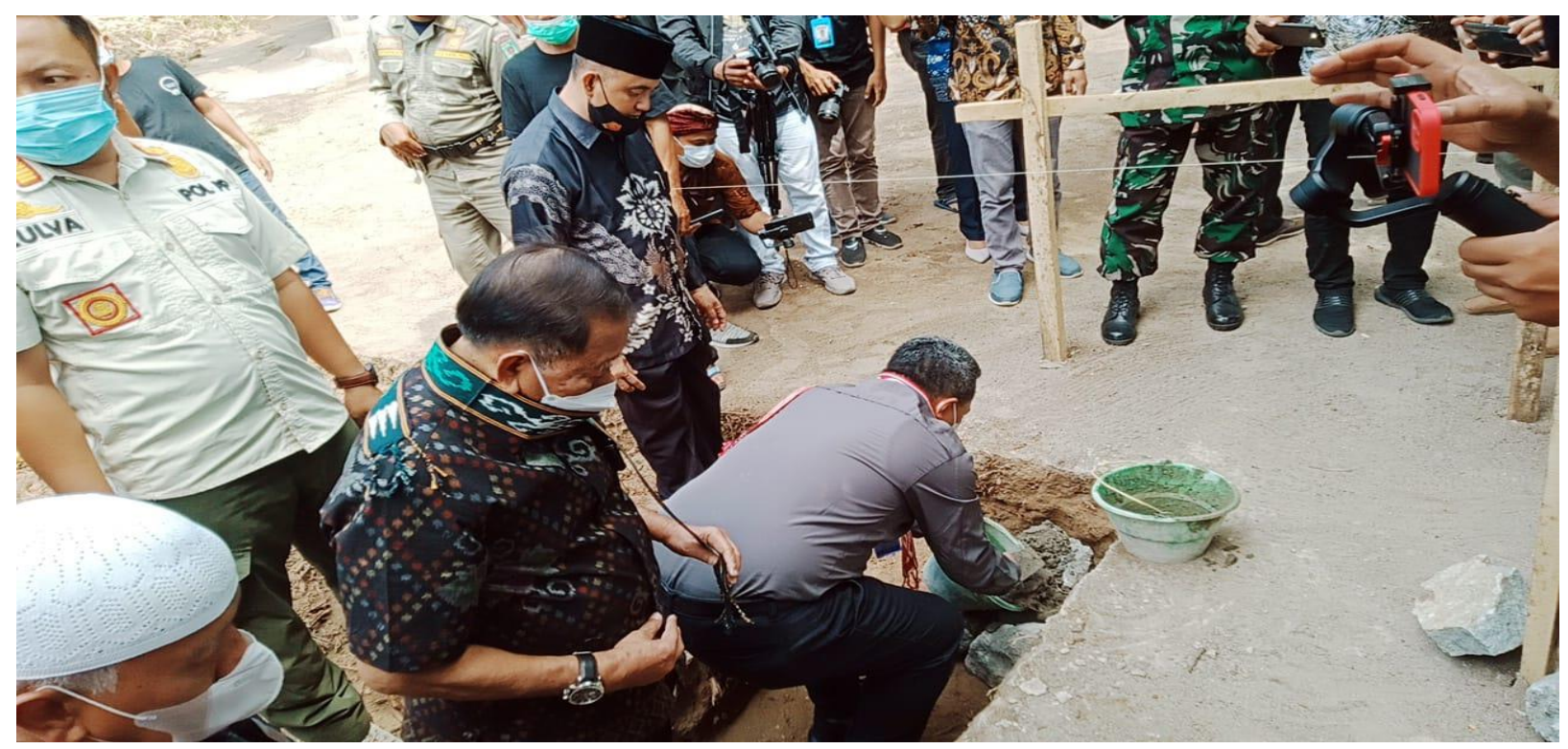

Gambar 4. Foto diatas merupakan peletakan batu pertama untuk pembangunan Homestay oleh Bupati KLU. ${ }^{15}$

\section{Wawancara}

Pengabdi mewawancarai beberapa masyarakat desa mengenai dampak apa yang mereka rasakan dengan adanya kebijakan pengalihan dana desa yang awalnya akan dialokasikan untuk pembangunan infrstruktur akibat gempa tahun 2018 silam, yang kemudian dialokasikan untuk dana bantuan masyarakat miskin yang terdampak Covid-19 sebagai praktik dari kebijakan pengalihan dana oleh Pemerintah desa.

Berikut merupakan hasil wawancara pengabdi dengan beberapa warga masyarakat yang menerima bantuan dana perekonomian.

${ }^{15}$ Foto diatas merupakan peletakan batu pertama untuk pembangunan Homestay di Dusun kecinan sebagai Badan Usaha Milik Desa (BUMDes) oleh Bupati KLU pada hari Kamis tanggal 22 Juli 2021 


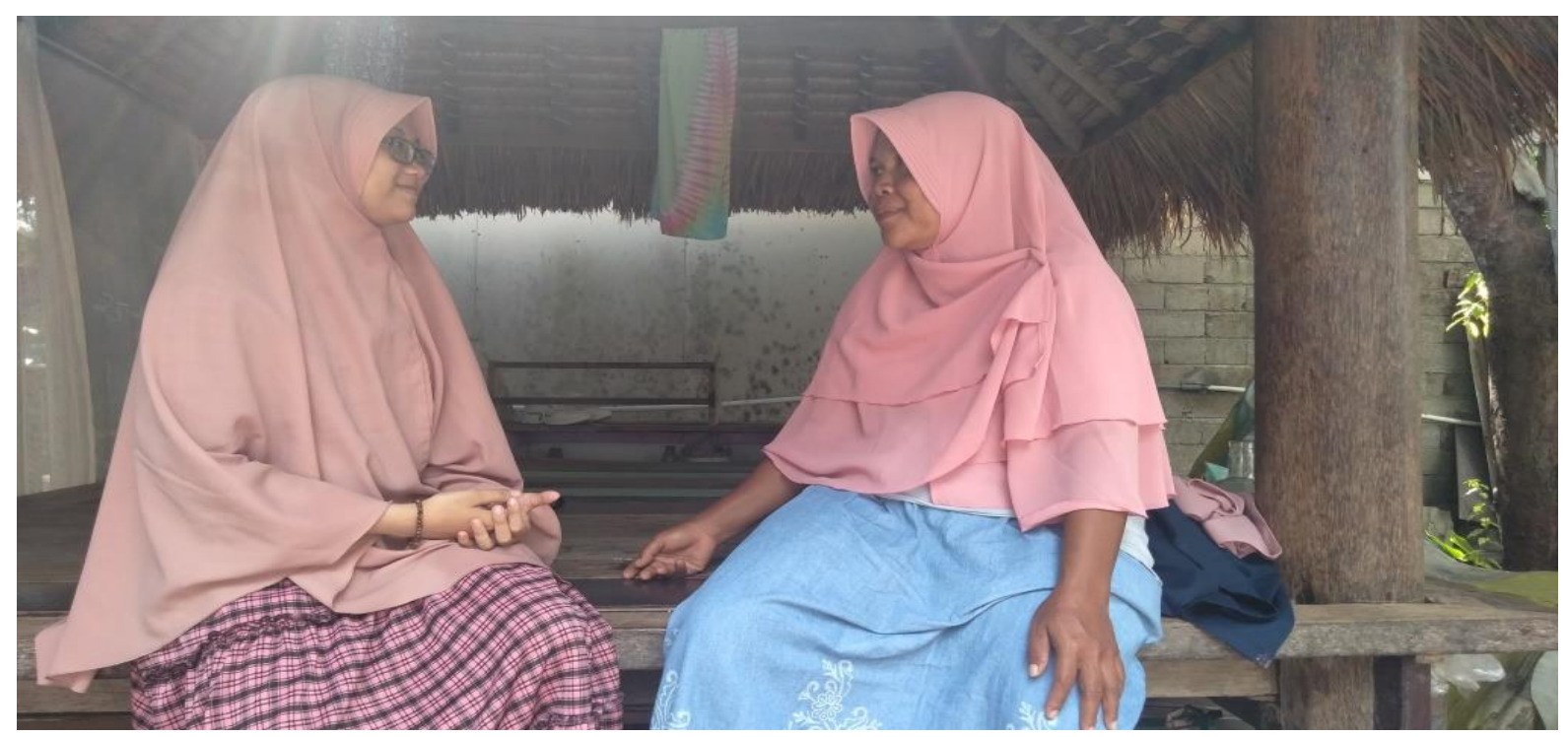

Gambar 5. Wawancara pertama ${ }^{16}$

Pengabdi mewawancarai warga masyarakat penerima bantuan PKH atas nama Ibu Hayati Dusun Pandanan Rt 4 mengatakan "saya merasa sangat terbantu dengan adanya bantuan PKH yang berupa beras sembako ini, selain itu bantuan PKH ini juga membantu anak saya dalam menerima bantuan tunjangan dana di sekolahnya."17

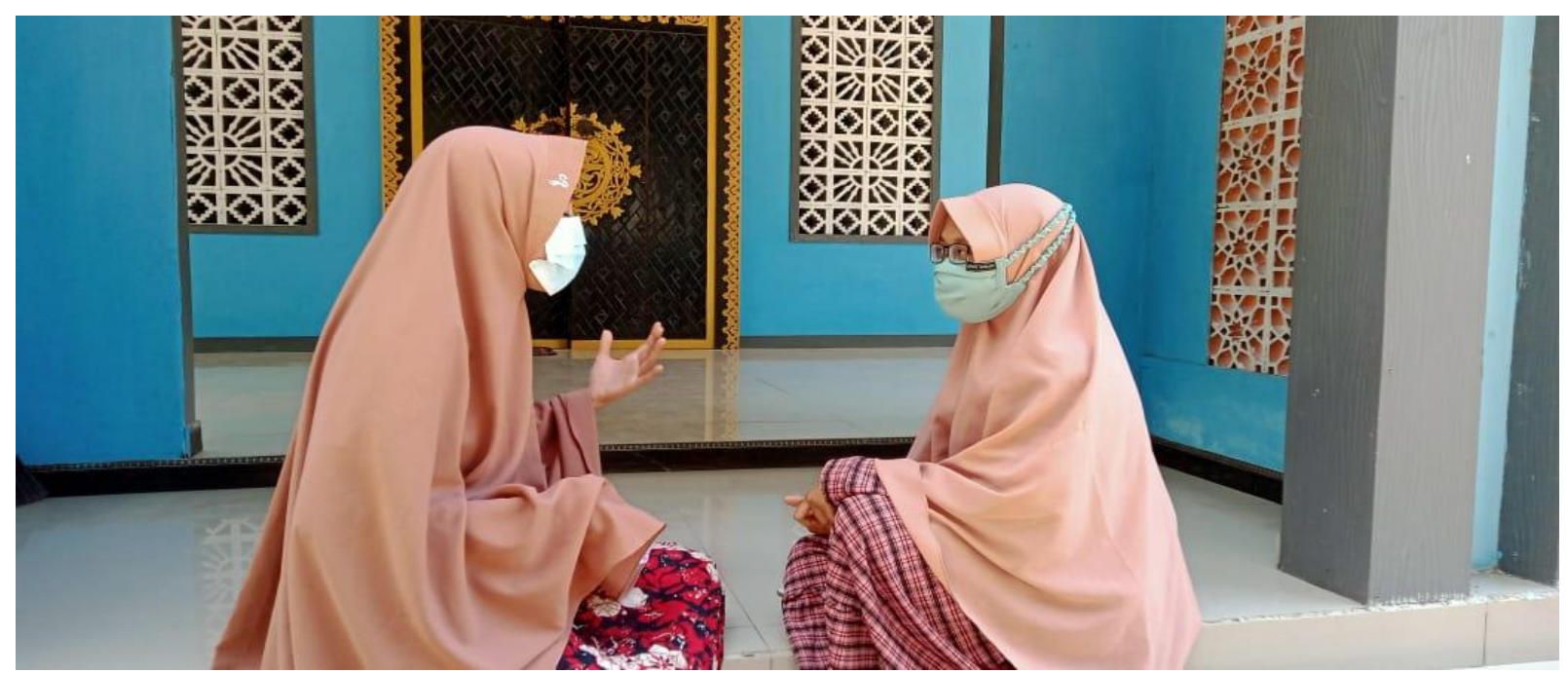

Gambar 6. Wawancara kedua ${ }^{18}$

${ }^{16}$ Foto wawancara pertama salah satu masyarakat penerima bantuan program PKH (Program Keluarga Harapan) pada hari Kamis 05 Agustus 2021

17 Tanggapan dari Ibu Hayati mengenai adanya bantuan program PKH oleh Pemerintah Desa Malaka

${ }^{18}$ Foto wawancara kedua salah satu masyarakat penerima bantuan program BLT (Bantuan Langsung Tunai) pada hari Kamis 05 Agustus 2021 
Kemudian di wawancara kedua, pengabdi mewawancarai salah satu masyarakat yang mendapat bantuan tunai langsung (BLT). Beliau bernama Ibu Harlin Suharni berasal dari dusun Pandanan, Beliau mengatakan bahwa sangat menyetujui dan mendukung aksi pemerintah desa dalam mengalihkan dana desa untuk pembangunan infrastruktur menjadi dana bantuan perekonomian masyarakat. Karna prioritas saat ini adalah ekonomi masyarakat yang sangat rendah bahkan banyak dari masyarakat yang membutuhkan bantuan pekerjaan, ujarnya. ${ }^{19}$

\section{Kesimpulan}

Pelaksanaan KKP-DR UIN Mataram sejak tanggal 2 Juli- 15 Agustus 2021 memeberikan kontribusi positif terhadap kebijakan pengalihan dana dari dana pembangunan inftastruktur menjadi dana bantuan untuk perekonomian masyarakat setempat, Di Desa Malaka KKP-DR dilakukan oleh kelompok 40. Selama kegiatan berlangsung, program yang sudah dilaksanakan berkaitan dengan tujuan membantu pemerintah desa untuk mensukseskan kegiatan pembagian dana perekonomian masyarakat setempat dalam Partisipatif Program.

Kegiatan-kegiatan yang pengabdi laksanakan kaitannya dengan memperhatikan apa saja solusi yang dilakukan oleh pemerintah desa menghadapi krisis perekonomian di Desa Malaka dan meneliti apa dampak yang diarasakan oleh masyarakat setempat mengenai adanya beberapa bantuan yang diusahakan oleh Pemerintah Desa sebagai praktik dari kebijakan pengalihan dana desa yang awalnya akan dialokasikan untuk pembangunan infrastruktur yang rusak akibat gempa tahun 2018 menjadi dana bantuan langsung guna menunjang perekonomian masyarakat semasa Covid-19.

Dan respon dari sebagian besar masyarakat desa adalah positif mengenai pengalihan dana ini. Karena sudah seyogyanya para pemerintah desa mengetahui mana hal yang terlebih dahulu di prioritaskan. Dan masyarakat desa merasa sangat terbantu oleh beberapa program bantuan yang diadakan oleh pemerintah desa Malaka.

\section{Ucapan Terimakasih}

Pengabdi ingin mengucapkan Terimakasih kepada P2M LPM UIN Mataram, karena telah memberikan kesempatan kepada mahasiswa dan mahasiswi untuk melakukan kegiatan pengabdian masyarakat dengan kegiatan KKP-DR di daerahnya masing-masing. Dengan berusaha ikut berpartisipasi dalam membantu Desa untuk mengatasi problem yang terjadi di Desa, pengabdi jadi dapat membagikan ilmu dan pengalaman yang telah diajarkan oleh segenap tim pendidik UIN Mataram kepada warga masyarakat sekitar. Semua kegiatan yang telah kami lakukan di Desa sudah pengabdi lakukan sesuai protokol kesehatan Covid-19 dan arahan yang telah diberikan oleh P2M LPM UIN Mataram, sehingga semua informasi yang terdapat pada artikel ini dapat terhimpun dengan baik dan akurat mengenai kontribusi UIN Mataram dalam

19 Tanggapan dari Ibu Harlin Suharni mengenai aksi pemerintah desa dalam mengalihkan dana desa untuk pembangunan infrastruktur menjadi dana bantuan perekonomian masyarakat di Desa Malaka

Rahmanita \& Jamhuri (2021), Dampak kebijakan pengaliban.........

| Vol. 01, No.02, 2021 | h. 91 
mengatasi permasalahan yang ada di Desa yakni ikut berpartisipasi dalam kegiatan pembagian bantuan kepada masyarakat menengah kebawah sebagai praktik dari kebijakan pengalihan dana desa dana yang awalnya hendak dialokasikan untuk pembangunan infrastruktur yang rusak akibat gempa tahun 2018 silam menjadi dana bantuan perekonomian untuk masyarakat Desa Malaka.

\section{Daftar Pustaka}

Akmaludin, Eskafi Eka. 2019. Strategi Pengembangan Parinisata Pasca Gempa Sebagai Upaya Meningkatkan Daya Saing Obyek, Wisata Di Kabupaten Lombok Utara. Jurnal Ilmu Manajemen. Vol. 8, Nomor 2, Desember 2019

Al-Kusaeri. 2021. Kontribusi KKP UIN Mataram dalam Meningkatkan Kesadaran Masyarakat Kembang Kerang mematubi Protocol Covid-19. Jurnal Pengabdian Pada Masyarakat. Vol. 01, No. 01, April 2021

Efendi, M. Harja. 2021. Model Sosialisasi Dan Pendampingan Mahasiswa KKP UIN Mataram Di Tengah Pandemi Covid-19. Jurnal Pengabdian Pada Masyarakat. Vol. 01, No. 01, April 2021

Faturrahman, Fadli. Saleh, M. Pathiassana, MT. Haryanti, Eka. 2020. Perubahan Alokasi Anggaran Dana Desa Terhadap Pencegahan Covid-19 Di Kecamatan Moyo bulu. Jurnal Tambora Vol. 4 No. 2a Juli 2020

Kementerian Keuangan Republik Indonesia. Buku Pintar Dana Desa. Jakarta pusat 10710

Kusuma, Dede Wahyu. Soeprapto, Viki Anggraini. Efektivitas Pengalihan Dana Dekonsentrasi dan Tugas Pembantuan ke Dana Alokasi Khusus.

Permendes PDTT, 2020. Prioritas Penggunaan dana Desa Tahun 2020. Online), (https://kemenkeu.go.id), diakses 3 Agustus 2021.

Perppu. 2020. Tentang Kebijakan keuangan Negara dan stabilitas Sistem Keuangan untuk Penanganan Pandemi Corona Virus Disease 2019 (Covid-19). (Online), (https://kemenkeu.go.id), diakses 3 Agustus 2021.

Perpres. 2020. Perubahan Postur dan Rincian Anggaran Pendapatan dan Belanja Negara Tabun Anggaran 2020. (Online), (https://kemenkeu.go.id), diakses 3 Agustus 2021.

PMK, 2020. Pengelolaan Transfer ke Daerah dan dana Desa Tabun Anggaran 2020. (Online), (www.djpk.kemenkeu.go.id), diakses 3 Agustus 2021.

Tangkumahat, Veiby Vencentia. Panelewen, Vicky V.J. mirah, Arie. D.P. 2017. Dampak Program dana Desa Terbadap Peningkatan Pembangunan dan Ekonomi di Kecamatan Pineleng Kabupaten Minahasa. Agri-SosioEkonomi Unsrat. Vol. 13, No. 2A, Juli 2017.

Rahmanita \& Jamhuri (2021), Dampak kebijakan pengalihan.........

| Vol. 01, No.02, 2021 | h. 92 